\title{
IAMJ
}

INTERNATIONAL

AYURVEDIC

MEDICAL JOURNAL

Research Article

ISSN: 2320-5091

Impact Factor: 6.719

\section{MANAGEMENT OF ASRIGDARA WITH DRAKSHADI YOGA AND KUTAJASHTAKA GHANA WITH SPECIAL REFERENCE TO DYSFUNCTIONAL UTERINE BLEEDING: A COMPARATIVE CLINICAL STUDY}

\author{
Meemansa $^{1}$, Manish Kumar Saini ${ }^{2}$, Sushila Sharma ${ }^{3}$ \\ ${ }^{1}$ Assistant Professor, Department of Prasuti Tantra \& Stri Roga, Shri Dhanwantri Ayurvedic Medical College \\ Hospital \& Research Centre, Mathura, Uttar Pradesh, India \\ ${ }^{2}$ Assistant Professor, Department of Rasa Shastra \& Bhaishjya Kalpana, Shri Dhanwantri Ayurvedic Medical Col- \\ lege \& Hospital, Mathura, Uttar Pradesh, India \\ ${ }^{3}$ Professor, Department of Prasuti Tantra \& Stri Roga, National institute of Ayurveda, Jaipur, Uttar Pradesh, India
}

Corresponding Author: meemansaswami21@gmail.com

https://doi.org/10.46607/iamj.1009012021

(Published online: January 2021)

Open Access

(C) International Ayurvedic Medical Journal, India 2021

Article Received: 29/12/2020 - Peer Reviewed: 31/12/2020 - Accepted for Publication: 02/01/2021

Check for updates

\begin{abstract}
Introduction: Asrigdara is of more concern, because excessive or prolonged bleeding may cause undue disruption of woman's daily activities \& affects woman's health both physically and psychologically. As per Ayurveda classics, Asrigdara is defined as excessive menstrual bleeding for prolonged duration and / or scanty intermenstrual bleeding for a shorter duration, denoting the features of specific Dosha. Asrigdara can be correlated with abnormal uterine bleeding especially dysfunctional uterine bleeding on the basis of its description in literature. Thus, according to its pathogenesis Pittashamaka, Vatanulomana, Rakta-sthapaka, Rakta-samgrahi, Agnideepana and Garbhashaya-balya Chikitsa is beneficial in Asrigdara. Though the main concern is to reduce bleeding, hence Rakta Sthapana chikitsa becomes important. Acharaya Charaka said it to be treated on the principles of management of Raktatisara, Raktapitta and Rakta arsha. Aim \& Objectives: To compare the efficacy of Drakshadi Yoga and Kutajashtaka Ghana in management of Asrigdara. Materials \& Methods: Study was conducted on clinically diagnosed 30 patients of Asrigdara in P.G. department of Prasuti Tantra and Stri Roga,
\end{abstract}


N.I.A., Jaipur. Drakshadi yoga was taken in this study from Sushruta Samhita Uttar Tantra 45/34 in reference to Raktapitta chikitsa. Kutajashtaka ghana (Chakradutta 3/86-89) was taken from Chakradutta from Atisaar Chikitsa, having indication in asrigdara. Result: Comparing the symptomatic improvement in both groups it was found that average percentage of relief was a little bit higher in 'Group B' Kutajashtaka Ghana i.e. 74.79 \%, followed by 'Group A' Drakshadi Yoga i.e. $74.21 \%$.

Keywords: Kutajashtaka Ghana, Drakshadi Yoga, Raktapitta chikitsa, Atisaar Chikitsa

\section{INTRODUCTION}

Woman is considered the main cause behind the development of this world in terms of giving birth to progeny. Almost all her health is being dependent on normalcy of her menstrual cycle. Menstruation and ovulation may be associated with significant bleeding leading to the limitation in conducting daily activities, changes in social functioning and adverse effect on quality of life ${ }^{1}$. At least $5-10 \%$ of women at reproductive age will seek medical attention for menorrhagia ${ }^{2}$. A variety of organic, endocrine, gynaecologic or other systemic causes may be responsible for menorrhagia; however, an underlying aetiology is identified in only $50 \%$ of cases $^{3}$. Abnormal uterine bleeding (AUB) is defined as any change in the frequency of menstruation, duration of flow or amount of blood loss. AUB is defined as dysfunctional uterine bleeding (DUB) when palpable pelvic pathology or underlying medical causes have been excluded. AUB is responsible for $20-30 \%$ of the visits to Gynecology Outpatient Department amongst women in the reproductive age group and $69 \%$ in a peri or postmenopausal age group. ${ }^{4}$ It has been stated in Charaka Samhita that due to Pradirana (excessive excretion) of Raja (menstrual blood), it is named as Pradara and since, there is Dirana (excessive excretion) of Asrik (menstrual blood) hence, it is known as Asirgdara ${ }^{5}$. Aacharya Sushruta says that when menstruation comes in excess amount, for prolonged period and/or even without normal period of menstruation and different from the features of normal menstrual blood or denoting the feature of specific Dosha is known as Asrigdara ${ }^{6}$. Asrigdara can be correlated with abnormal uterine bleeding specially, dysfunctional uterine bleeding
(DUB) on the basis of its description in literature. About $10-15 \%$ of women experience episodes of abnormal uterine bleeding (AUB) at some time during the reproductive years of their lives. It is common during the extremes of reproductive life, following pregnancy and during lactation. ${ }^{7}$ In addition, it is the commonest cause of iron deficiency in the developed world and of chronic illness in the developing world. Acharaya Charaka said it to be treated on the principles of management of Raktatisara, Raktapitta and Rakta arsha ${ }^{8}$. The general principles of treatment of Asrigdara are as follows": Nidana Parivarjana, Dosha Shodhana, Dosha Shamana, Raktasamgrahana - Rakta Shodhana - Rakta Sthapana, Use of Tikta Rasa (Deepana-Pachana). Drakshadi yoga because of its Madhura-Tikta Rasa, Sheeta Veerya, Pittashamaka, Raktasamgrahi and Raktasthapaka properties and Kutajashtaka ghana because of its rakta-samgrahi and upshoshaka property have been taken in the present study to rule out and compare their therapeutic efficacy in the management of Asrigdara. The present study was undertaken in the Department of Prasuti Tantra \& Stri Roga, National Institute of Ayurveda, Jaipur. Patients who were diagnosed to have Asrigda$r a$ were registered and selected for the study.

AIM \& OBJECTIVES: To compare the efficacy of Drakshadi Yoga and Kutajashtaka Ghana in management of Asrigdara

\section{Trial drugs}

1. Drakshadi yoga (Sushruta samhita uttar tantra 45/32)

2. Kutajashtaka ghana (Chakradutta 3/86-89) 


\section{Drug Review}

Table D.R. 01: showing the contents of DRAKSHADI YOGA

\begin{tabular}{|l|l|l|l|l|}
\hline S.n. & Ingredient & Scientific name & Useful part & Quantity \\
\hline 1. & Draksha & Vitis vinifera Linn. & Phala & 1 part \\
\hline 2. & Sita & Saccharum officinarum Linn. & $\ldots \ldots . .$. & 1 part \\
\hline 3. & Tiktakarohini (Kutaki) & Picrorhiza kurroa Royle ex Benth & Moola & 1 part \\
\hline 4. & Mulethi & Glycyrrhiza glabra Linn. & Moola & 1 part \\
\hline
\end{tabular}

\begin{tabular}{|l|l|l|l|l|}
\hline S.no. & Ingredient & Scientific name & Useful part & Quantity \\
\hline 1. & Kutaja & Holarrhena antidysenterica Linn. & Kand-Twak & 100 parts \\
\hline 2. & Shalmali & Salmalia malabarica Schott \& Endl. & Moola & 1 part \\
\hline 3. & Patha & Cissampelos pareira Linn. & Moola & 1 part \\
\hline 4. & Samanga & Mimosa pudica Linn. & Panchanga & 1 part \\
\hline 5. & Ativisha & Aconitum heterophylum Wall & Moola & 1 part \\
\hline 6. & Musta & Cyperus rotundus Linn. & Kand(Tuber) & 1 part \\
\hline 7. & Bilwa & Aegle marmelos Corr. & Moola & 1 part \\
\hline 8. & Dhatki & Woodfordia fruticosa Kurz. & Pushpa & 1 part \\
\hline
\end{tabular}

Table D.R. 02: showing the contents of KUTAJASHTAKA- GHANA

Materials and Methods:

Drawing up a Protocol: This study was conducted under a strict protocol to prevent bias and to reduce the sources of error in the study.

Selection of Cases: Total 30 clinically diagnosed and confirmed cases of Asrigdara completed the course of treatment. The cases were selected from the O.P.D. / I.P.D. of P.G. Department of Prasuti tantra \& Stri Roga, National Institute of Ayurveda (N.I.A.) Hospital, Jaipur after taking informed written consent.

Criteria for selection of patients:

Inclusion criteria: Patients of age group 12 to 50 years and Patients complaining of Asrigdara having any two of the following symptoms: Heavy menstrual bleeding (amount $>80 \mathrm{ml}$ ) or Prolonged menstrual bleeding (With the duration of bleeding $>7$ days) or Inter menstrual bleeding or Frequent menstrual cycle (interval $<21$ days)
Exclusion criteria: Patients having bleeding due to abortion, coagulation disorders, bleeding after menopause, any type of malignancy, STDs, any systemic diseases, Uterine and pelvic pathology like- Polyps, Endometrial TB, Fibroid, Adenomyosis, PID etc., Patients using IUCDs. \& pregnant woman.

Design of the study:

1. Study type: Interventional

2. Intervention model: Two group assignment

3. Allocation: Randomized (by Lottery method)

4. Masking: Open label

5. Purpose: Treatment

6. Timing: 2 Months

7. End point: Efficacy

8. Subjects: 15 patients in each group.

Investigations: Laboratory investigations were carried out before treatment to rule out any other pathological conditions and after completion of trial to rule out the improvement in laboratory parameters.

\footnotetext{
Administration of drugs:

Group A: $\quad 15$ Patients were treated by Drakshadi yoga orally.

Dose- 5 gm twice daily with sheetal jala as Anupana.

Group B: $\quad 15$ Patients were treated by Kutajashtaka ghana orally.

Dose- $500 \mathrm{mg}$ twice daily with sheetal jala as Anupana.
} 
Duration of clinical trial: Both the Drugs were started from seven days before due date of menstrual cycle and continued for 60 days/2 consecutive menstrual cycles.

Criteria of Assessment: The improvement in the patient was assessed mainly on the basis of relief in the signs and symptoms of the disease. To assess the ef- fect of therapy objectively, all the signs and symptoms were given scoring depending upon their severity.

Subjective Assessment: The patients were assessed for Rakta Sthapaka property on the basis of symptom rating score for improvement in specific symptomatology of Asrigdara.

Subjective Parameters:

a) Intensity of Menstrual flow:

Max. no. Of Sanitary Pads in one day

$\leq 3$ pads

$>3$ - 4 Pads

$>4$ - 5 Pads

More than 5 Pads

\begin{tabular}{|l|} 
Score \\
\hline 0 \\
1 \\
\hline 2 \\
3
\end{tabular}

\section{b) Amount of flow/bleeding:}

\section{Amount of flow}

$\leq 15$ pads

16-20 pads

21-25 pads

$>25$ pads

Score
0
1
2
3

c) Duration of Menstrual bleeding:

\begin{tabular}{|l|l}
\hline Duration of menstrual flow & Score
\end{tabular}

\begin{tabular}{|l|l|l|}
\hline Up to 5 days & 0 \\
\hline $6-7$ days
\end{tabular}

\begin{tabular}{l|l|l|}
\hline $6-7$ days & 1 \\
\hline $8-9$ days &
\end{tabular}

\begin{tabular}{|l|l|}
\hline $8-9$ days & 2 \\
\hline
\end{tabular}

\begin{tabular}{|l|l|l|l}
\hline More than 9 days & 3
\end{tabular}

d) Intermenstrual Period:

\begin{tabular}{|l|l|}
\hline Interval between two cycles & Score \\
\hline $25-28$ Days & 0 \\
\hline 20-24 Days & 1 \\
\hline 15-19 Days & 2 \\
\hline
\end{tabular}

\section{e) Body Ache:}

\section{Body ache}

Occasionally on doing heavy Work

After doing extra work

After doing Routine Work

Even during rest

\begin{tabular}{|l|}
\hline Score \\
\hline 0 \\
\hline 1 \\
\hline 2 \\
\hline 3 \\
\hline
\end{tabular}




\section{f) Burning Sensation:}

\begin{tabular}{|l|l|}
\hline Burning Sensation & Score \\
\hline No Burning & 0 \\
\hline Burning sensation occasionally & 1 \\
\hline Often Burning sensation & 2 \\
\hline Regular or every time burning & 3 \\
\hline
\end{tabular}

\section{Objective Parameters:}

\section{a) Pallor}

\begin{tabular}{|l|l|}
\hline Grading of Pallor & Score \\
\hline No pallor & 0 \\
\hline Mild & 1 \\
\hline Moderate & 2 \\
\hline Severe & 3 \\
\hline
\end{tabular}

\section{Results of Therapeutic Trial:}

Intra-Group Comparison:

Table R-1: Shows the pattern of clinical recovery in various 'Subjective Parameters' of Asrigdara in 15 patients treated with 'orally -Drakshadi Yoga Group-A' by Wilcoxon matched-pairs signed-ranks test.

\begin{tabular}{|c|l|l|l|l|l|l|l|l|l|}
\hline $\begin{array}{l}\text { S. } \\
\text { No. }\end{array}$ & Symptom & Mean & Diff. & $\begin{array}{l}\% \\
\text { Relief }\end{array}$ & of & SD & SE & P & $\begin{array}{l}\text { Significance } \\
\text { Results }\end{array}$ \\
\hline 1. & Intensity & AT & & & & & \\
\hline 2. & Amount & 2.733 & 0.7333 & 2.000 & 73.17 & 0.3780 & 0.09759 & $<0.001$ & E.S. \\
\hline 3. & Duration & 2.533 & 0.6667 & 1.867 & 73.70 & 0.3519 & 0.09085 & $<0.001$ & E.S. \\
\hline 4. & Inter-menstrual period & 1.667 & 0.3333 & 1.333 & 79.96 & 0.6172 & 0.1592 & $<0.001$ & E.S. \\
\hline 5. & Body ache & 1.667 & 0.1333 & 0.7333 & 68.72 & 0.7037 & 0.1817 & $<0.01$ & V.S. \\
\hline 6. & Burning sensation & 0.9333 & 0.1333 & 1.067 & 64.00 & 0.2582 & 0.0666 & $<0.001$ & E.S. \\
\hline
\end{tabular}

Table R-2: Shows the pattern of clinical recovery in Pallor in 15 patients treated with 'orally -'Drakshadi Yoga Group A' by Wilcoxon matched-pairs signed-ranks test.

\begin{tabular}{|l|l|l|l|l|l|l|l|l|l|}
\hline $\begin{array}{l}\text { S. } \\
\text { No. }\end{array}$ & Variable & Mean & Dif. & \% of Relief & SD & SE & P & \\
\cline { 2 - 8 } & BT & AT & & & & & & Result \\
\hline 1. & Pallor & 1.067 & 0.867 & 0.2000 & 18.74 & 0.4140 & 0.1069 & $>0.05$ & N.S. \\
\hline
\end{tabular}

Analysis of subjective parameters and pallor of Group A as per table R-1 \& R-2

$>$ Statistically extremely significant results $(p<0.001)$ were found in Intensity, Amount, Duration of bleeding and Bodyache.
$>$ Statistically very significant result $(\mathrm{p}<0.01)$ was found in intermenstrual period and burning sensation.

$>$ Statistically non-significant result $(\mathrm{p}>0.05)$ was found in Pallor.

Table R-3: Shows the pattern of clinical recovery in various 'Objective Parameters' of Asrigdara in 15 patients treated with "Drakshadi Yoga” orally - 'Group A' by Paired 't' test.

\begin{tabular}{|c|l|l|l|l|l|l|l|l|l|l|}
\hline $\begin{array}{c}\text { S. } \\
\text { N. }\end{array}$ & Parameter & Mean & Diff & \% of relief & SD & SE & t Value & P Value & Result \\
\cline { 1 - 11 } & BT & AT & & & & & & & \\
\hline 1. & BP (Sys) & 110.33 & 113.33 & -3.333 & 3.02 & 4.880 & 1.260 & 2.646 & $>0.05$ & N.S. \\
\hline 2. & BP (Dias) & 70.000 & 72.667 & -2.667 & 3.81 & 5.936 & 1.533 & 1.740 & $>0.05$ & N.S. \\
\hline 3. & Pulse Rate & 76.000 & 74.933 & 1.067 & 1.40 & 2.815 & 0.7268 & 1.468 & $>0.05$ & N.S. \\
\hline 4. & Respiratory Rate & 18.533 & 18.400 & 0.1333 & 0.72 & 1.187 & 0.3065 & 0.4350 & $>0.05$ & N.S. \\
\hline
\end{tabular}


Table R-4: Shows the pattern of clinical recovery in various 'Laboratory Investigations' of Asrigdara in 15 patients treated with 'Drakshadi yoga" orally - 'Group A' by Paired 't' test.

\begin{tabular}{|c|c|c|c|c|c|c|c|c|c|c|}
\hline S. & Variable & Mean & & Dif. & $\%$ of & SD & SE & ' $t$ ' & $\mathrm{P}$ & Results \\
\hline No. & & BT & AT & & Relief & & & & & \\
\hline 1. & $\begin{array}{l}\mathrm{Hb} \\
(\mathrm{gm} \%)\end{array}$ & 11.753 & 11.993 & -0.2400 & 2.04 & 0.5865 & 0.1514 & 1.585 & $>0.05$ & N.S. \\
\hline 2. & TLC & 7940.0 & 7260.0 & 680.0 & 8.56 & 2708.5 & 699.33 & 0.9724 & $>0.05$ & N.S. \\
\hline 3. & ESR & 16.600 & 12.867 & 3.733 & 22.48 & 5.021 & 1.296 & 2.880 & $<0.05$ & S. \\
\hline 4. & CT & 4.102 & 4.061 & 0.04067 & 0.99 & 0.8360 & 0.2159 & 0.1884 & $>0.05$ & N.S. \\
\hline 5. & BT & 2.228 & 2.295 & -0.0666 & 2.98 & 0.3680 & 0.095 & 0.7017 & $>0.05$ & N.S. \\
\hline 6. & $\begin{array}{l}\text { Total } \\
\text { Platelet } \\
\text { count }\end{array}$ & 2.346 & 2.447 & -0.1007 & 4.29 & 0.9287 & 0.2398 & 0.4198 & $>0.05$ & N.S. \\
\hline
\end{tabular}

Table R-5: Shows the pattern of clinical recovery in various 'Subjective Parameters' of Asrigdara in 15 patients treated with “Kutajashtaka-Ghana” orally - 'Group B' by Wilcoxon matched-pairs signed-ranks test.

\begin{tabular}{|c|c|c|c|c|c|c|c|c|c|c|}
\hline \multirow[t]{2}{*}{ S. No. } & \multirow[t]{2}{*}{ Symptoms } & \multicolumn{2}{|l|}{ Mean } & \multirow[t]{2}{*}{ Diff. } & \multirow[t]{2}{*}{$\%$ of } & \multirow[t]{2}{*}{ Relief } & \multirow[t]{2}{*}{ SD } & \multirow[t]{2}{*}{ SE } & \multirow[t]{2}{*}{$\mathbf{P}$} & \multirow[t]{2}{*}{ Results } \\
\hline & & BT & AT & & & & & & & \\
\hline 1. & Intensity & 2.333 & 0.5333 & 1.800 & 77.15 & & 0.6761 & 0.1746 & $<0.001$ & E.S. \\
\hline 2. & Amount & 2.200 & 0.3333 & 1.867 & 84.86 & & 0.6399 & 0.1652 & $<0.001$ & E.S. \\
\hline 3. & Duration & 1.9333 & 0.2667 & 1.667 & 86.24 & & 1.047 & 0.2702 & $<0.001$ & E.S. \\
\hline 4. & Inter menstrual period & 1.267 & 2.000 & 1.067 & 84.21 & & 0.9612 & 0.2482 & $<0.01$ & V.S. \\
\hline 5. & Body ache & 1.733 & 0.5333 & 1.200 & 69.24 & & 0.4140 & 0.1069 & $<0.001$ & E.S. \\
\hline 6. & Burning sensation & 1.133 & 0.6000 & 0.5333 & 47.06 & & 0.6399 & 0.1652 & $<0.05$ & S. \\
\hline
\end{tabular}

Table R-6: Shows the pattern of clinical recovery in Pallor in 15 patients treated with 'orally -'Kutajashtaka Ghana Group B' by Wilcoxon matched-pairs signed-ranks test.

\begin{tabular}{|c|l|l|l|l|l|l|l|l|c|}
\hline $\begin{array}{l}\text { S. } \\
\text { No. }\end{array}$ & Variable & Mean & Dif. & $\begin{array}{l}\text { \% of } \\
\text { Relief }\end{array}$ & SD & SE & P & Result \\
\hline 1. & Pallor & 1.267 & 0.8000 & 0.4667 & 36.83 & 0.5164 & 0.1333 & $<0.05$ & S. \\
\hline
\end{tabular}

Analysis of subjective parameters and pallor of Group B as per table no. R-5 \& R-6
Statistically very significant result $(\mathrm{p}<0.01)$ was found in inter menstrual period.

$>$ Statistically extremely significant results $(\mathrm{p}<0.001)$ were found in Intensity, amount, duration of bleeding and bodyache.

$>$ Statistically significant result $(\mathrm{p}<0.05)$ was found in burning sensation and Pallor.

Table R-7: Shows the pattern of clinical recovery in various 'Objective Parameter' of Asrigdara in 15 patients treated with "Kutajashtaka-Ghana” orally - 'Group B' by student paired t test.

\begin{tabular}{|c|l|l|l|l|l|l|l|l|l|l|}
\hline $\begin{array}{l}\text { S. } \\
\text { No. }\end{array}$ & Parameters & Mean & Diff & $\begin{array}{l}\% \text { of } \\
\text { relief }\end{array}$ & SD & SE & t Value & P Value & Result \\
\cline { 2 - 10 } 1. & BP (Sys) & 112.67 & 114.00 & -1.333 & 1.18 & 6.399 & 1.652 & 0.8069 & $>0.05$ & N.S. \\
\hline 2. & BP (Dias) & 73.333 & 72.667 & 0.667 & 0.90 & 7.037 & 1.817 & 0.3669 & $>0.05$ & N.S. \\
\hline 3. & Pulse Rate & 75.200 & 74.267 & 0.9333 & 1.24 & 3.369 & 0.8700 & 1.073 & $>0.05$ & N.S. \\
\hline 4. & $\begin{array}{l}\text { Respiratory } \\
\text { Rate }\end{array}$ & 19.067 & 18.533 & 0.5333 & 2.79 & 1.407 & 0.3634 & 1.468 & $>0.05$ & N.S. \\
\hline
\end{tabular}


Table R-8: Shows the pattern of clinical recovery in various 'Laboratory investigations' of Asrigdara in 15 patients treated with 'Kutajashtaka-Ghana” orally - 'Group B' by Paired 't' test.

\begin{tabular}{|c|l|l|l|l|l|l|l|l|l|l|}
\hline $\begin{array}{l}\text { S. } \\
\text { No. }\end{array}$ & Variable & Mean & Dif. & $\begin{array}{l}\text { \% of } \\
\text { Relief }\end{array}$ & SD & SE & 't' & P & Results \\
\hline 1. & Bb $(\mathrm{gm} \%)$ & 11.000 & 11.287 & -0.2867 & 2.60 & 0.9257 & 0.2390 & 1.199 & $>0.05$ & N.S. \\
\hline 2. & TLC & 7789.3 & 6760.0 & 1033.3 & 13.26 & 2682.4 & 692.59 & 1.492 & $>0.05$ & N.S. \\
\hline 3. & ESR & 17.333 & 12.067 & 5.267 & 30.39 & 7.196 & 1.858 & 2.835 & $<0.05$ & S. \\
\hline 4. & CT & 4.538 & 4.334 & 0.2040 & 4.49 & 0.9390 & 0.2425 & 0.8414 & $>0.05$ & N.S. \\
\hline 5. & BT & 2.537 & 2.291 & 0.2453 & 9.66 & 0.6068 & 0.1567 & 1.566 & $>0.05$ & N.S. \\
\hline 6. & $\begin{array}{l}\text { Total Platelet } \\
\text { count }\end{array}$ & 2.993 & 1.953 & 1.040 & 34.75 & 1.092 & 0.2819 & 3.689 & $<0.01$ & V.S. \\
\hline
\end{tabular}

Intergroup Comparison:

- Inter Group Comparison in Subjective Parameters \& Pallor by Mann Whitney Test: Statistically non-significant result ( $p>0.05$ ) was found
- Inter Group Comparison on Objective parameters \& Laboratory investigations of Asrigdara by Unpaired ' $t$ ' Test: Statistically nonsignificant result $(\mathrm{p}>0.05)$ was found in all the objective and laboratory parameters.

Table R-9: \% Improvement of Subjective Parameters in Both Groups:

\begin{tabular}{|c|l|l|l|}
\hline S.N. & Parameters & Result in Percentage & \\
\cline { 3 - 4 } & & Group A (in \%) & Group B (in \%) \\
\hline $\mathbf{1 .}$ & Intensity & 73.17 & 77.15 \\
\hline $\mathbf{2 .}$ & Amount & 73.70 & 84.86 \\
\hline $\mathbf{3 .}$ & Duration & 79.96 & 86.24 \\
\hline $\mathbf{4 .}$ & Inter menstrual Period & 68.72 & 84.21 \\
\hline $\mathbf{5 .}$ & Bodyache & 64.00 & 69.24 \\
\hline $\mathbf{6 .}$ & Burning sensation & 85.72 & 47.06 \\
\hline Average \% & Of Relief & $\mathbf{7 4 . 2 1}$ & $\mathbf{7 4 . 7 9}$ \\
\hline
\end{tabular}

\section{DISCUSSION}

Asrigdara should be treated according to line of treatment of Raktarsha; Deepana, Pachana, Agni Vardhana, Rakta Sangrahana and Dosha Pachana should be done by Tikta \& Kashaya Rasa Pradhana Dravya $^{10}$. Drugs of Drakshadi yoga possess MadhuraTikta Rasa, Snigdha-Guru-Mridu-Ruksha-Laghu Guna, Katu-Madhura Vipaka and Sheeta Veerya. Analysis of various contents of Kutajashtaka Ghana reveals that: Deepana, Pachana, Raktastambhana, RaktaSangrahi, Raktaprasadana, Balya activity was present in all the drugs. While Dahaprashamana activity was found in Shalmali, Patha, Dhataki, Trishnanigrahana property in Musta, Yakrituttejaka and Pittasaraka property in Bilwa. All the components of Kutajashtaka Ghana were Kaphapittashamak, while Patha and Ativisha were found Tridoshshamaka and Bilwa was Kaphavatashamaka.

\section{CONCLUSION}

Artava being agneya in character is likely to increase tejas mahabhuta of the body, which may cause increase in the amount of pitta. Thus, during reproductive age and premenopausal age pitta dosha is predominant and chances of developing the pathogenesis of asrigdara are more. Apana Vayu is responsible for Pravartana of Artava and Vyana Vayu supply the blood to the uterus and pelvic organs. In pathogenesis of Asrigdara overall the amount of blood within the vessels of uterus increases or in other words, active or passive pelvic congestion is the main cause. In initiation of Samprapti of Asrigdara prominent Doshas are Vata and Pitta. These Doshas have predominant role in all type of Asrigdara. The main principle of the management of Asrigdara is Angi-deepana, Doshapachana, Vata-anulomana, Pittashamana, RaktaSthapana, Rakta-samgrahana, Raktashodhana, and 
Garbhashaya-balya Chikitsa. Deepaniya and $\mathrm{Pa}$ chaniya drugs are essential in the treatment of Asrigdara for proper functioning of Agni which helps in proper metabolism of oestrogen. The drug selected for this study Drakshadi-Yoga and Kutajashtakaghana possess all the qualities as mentioned above. Comparing the symptomatic improvement in both groups it was found that average percentage of relief

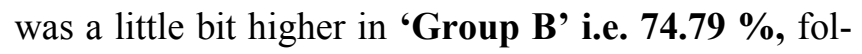
lowed by 'Group A' i.e. 74.21 \%. It shows that effect of therapy was more in Group B than in comparison to Group A.

\section{REFERENCES}

1. https://onlinelibrary.wiley.com/doi/full/10.1111/j.15387836.2011.04372.x

2. Kouides PA. Bleeding symptom assessment and hemostasis evaluation of menorrhagia. Curr Opin Hematol 2008; 15: 465-72.

3. Warner P, Critchley HO, Lumsden MA, Campbell-Brown M, Douglas A, Murray G.Referral for menstrual problems: cross sectional survey of symptoms, reasons for referral, and management. $\mathrm{Br}$ Med J2001; 323: 24-8.

4. H Hatasaka. The evaluation of abnormal uterine bleeding. Clin obstet Gynecol 2005;48(2).
5. Charak Samhita of Agnivesha, elaborated by Charak \& Dridhabala, Ayurveda Dipika commentary by Chakrapani datta, edited by Vaidya Yadav ji trikam ji Acharya, Chikitsa Sthana, Yonivyapatchikitsa, 30/209; Chaukhamba Surbharati Prakashan, Varanasi; 2016; Pp. 643

6. SSushruta Samhita of Maharshi Sushruta, Edited with Ayurveda-Tattva-Sandipika hindi commentary by Kaviraja Ambikadutta Shastri, Part-1, Sharir Sthan 2/20, Chaukhabha Sanskrit Sansthan, Varanasi; 2014, Pp. 15

7. Howkins\& Bourne, Shaw's Textbook of Gynaecology, edited by V G Padubidri and Shirish N Daftary, $16^{\text {th }}$ edition, Elsevier publication,2015; chapter 24; Pp. 339

8. Agnivesha, Charak, Dridhbala, Charak Samhita, Chikitsa Sthana,Yonivyapatchikitsa, 30/228, elaborated Vidyotini Hindi Commentary by Pt. Kashinatha Shastri and Dr. Gorakha Natha Chaturvedi, Part-2, Chaukhamba Bharti Academy, Varanasi; 2009, Pp. 870

9. Nirmala G. Joshi, Ayurvedic concepts in Gynaecology, edition $2^{\text {nd }}$, Chapter 7, Abnormal haemorrhage from uterus and vagina, Chaukhamba Sanskrit Pratishthan, Delhi; 1999; Pp. 84-85

10. Agnivesha, Charaka, Dridhbala, Charaka Samhita, Chikitsa Sthana,Arsha chikitsa, 14@182, elaborated Vidyotini Hindi Commentary by Pt. Kashinatha Shastri and Dr. Gorakha Natha Chaturvedi, Part-2 Chaukhamba Bharti Academy, Varanasi, 2009; Pp. 441

\section{Source of Support: Nil \\ Conflict of Interest: None Declared}

How to cite this URL: Meemansa et al: Management Of Asrigdara With Drakshadi Yoga And Kutajashtaka Ghana With Special Reference To Dysfunctional Uterine Bleeding: A Comparative Clinical Study. International Ayurvedic Medical Journal \{online\} 2021 \{cited January, 2021\} Available from: http://www.iamj.in/posts/images/upload/73_80.pdf 